\title{
Effects of Temperature and Heating Time on Degradation and Antioxidant Activity of Anthocyanin from Roselle Petals (Hibiscus sabdariffa L.)
}

\author{
Meiny Suzery ${ }^{1 *}$, Burhan Nudin ${ }^{1}$, Damar Nurwahyu Bima ${ }^{1}$, Bambang Cahyono ${ }^{1}$ \\ ${ }^{1}$ Department of Chemistry, Science and Mathematics Faculty, Diponegoro University, Semarang, \\ Indonesia, 50275 \\ *Corresponding Author \\ Email: meiny.suzery@live.undip.ac.id
}

\begin{abstract}
The effects of temperature and heating time on the degradation and antioxidant activity of anthocyanin compounds from roselle petals (Hibiscus sabdariffa L.) have been evaluated from this research. The purpose of this study is to determine, the degradation and antioxidant activity of anthocyanin compounds on variations of temperature and heating time. In this study anthocyanin was extracted from roselle petals using ethanol solvent at $25^{\circ} \mathrm{C}$. Then the anthocyanin extract obtained was dissolved into aqueous solution. The solution was then heated at $40^{\circ} \mathrm{C}, 60^{\circ} \mathrm{C}$ and $80^{\circ} \mathrm{C}$ for 60 minutes. The degradation of anthocyanin compounds was analyzed by calculating the total of anthocyanin contents, while the antioxidant activity was evaluated using the DPPH method. The results showed that Total Anthocyanin Content (TAC) from the extract solution before heating was $144.28 \mathrm{mg} / \mathrm{L}$. Meanwhile the total value of anthocyanin in the 60 minutes after heating at $40^{\circ} \mathrm{C}, 60^{\circ} \mathrm{C}$ and $80^{\circ} \mathrm{C}$ are $108.88 \mathrm{mg} / \mathrm{L}, 88.84 \mathrm{mg} / \mathrm{L}$ and 63.78 $\mathrm{mg} / \mathrm{L}$ respectively. Heating at $80^{\circ} \mathrm{C}$ decreases antioxidant activity by increasing the IC50 value to 86.8 ppm higher than the conditions before heating. The increase of temperature and length of the heating process made the anthocyanin structure degraded. Degradation was indicated by the reduction of total anthocyanin content and the decrease of antioxidant activity.
\end{abstract}

Keywords: Roselle; Anthocyanin; Stability; Degradation; Antioxidant

\section{INTRODUCTION}

Plants can be used as a source of natural pigments and safer food coloring, they have a low toxic effect. Among the compounds in plants that can be used as natural dyes are anthocyanin compounds [1]. Anthocyanins are compounds that give the red, blue and purple colors in plants [2]. One of the plants that contain anthocyanin compounds is rosella flower (Hibiscus sabdariffa L.). From previous study anthocyanin compounds have antioxidant activity $[3,4]$. Petals from rosella can be used as a substitute source for synthetic antibiotics [5].

Temperature, heating time and storing time will affect anthocyanin stability [6]. Food and beverage processing usually involve heating from $50^{\circ} \mathrm{C}$ until $150^{\circ} \mathrm{C}$. Anthocyanin stability is not only function of final heating temperature but also 
influenced by intrinsic properties of product and processing such as $\mathrm{pH}$, temperature of storage, chemical structure, light, oxygen, enzyme and protein [7]. The structure of anthocyanin can be shown in three types depend on the color there are Cyanidin, Pelargonidin, Delphinidin. The types of Anthocyanin structure show in figure 1 .

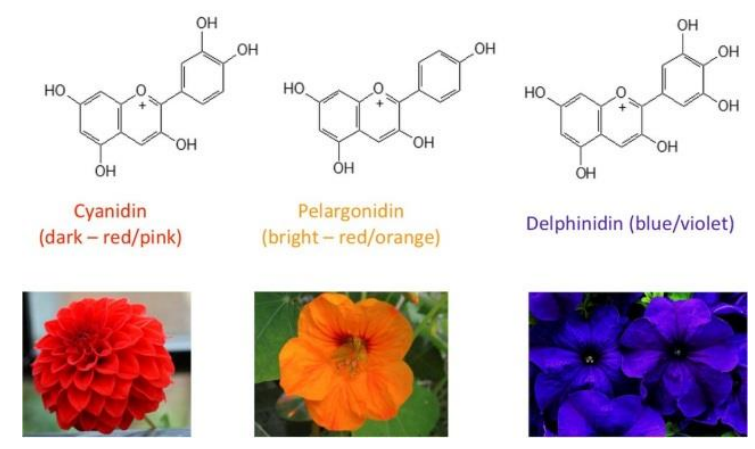

Figure 1. Types of Anthocyanin Structure

The three types of anthocyanin structures can be distinguished from the number of hydroxyl groups attached to the parent compound. The number of - $\mathrm{OH}$ groups contained in anthocyanins causes these compounds to have potential as antioxidants. Anthocyanin obtained by extracting roselle petals. Because the colour of Roselle petals extract were red so anthocyanin that were extracted known as Cyanidin-3-O-glucoside. Extraction process affecting the total of anthocyanin content. Based on study by Suzeryet, all., (2010), most optimum extraction process is maceration at $25^{\circ} \mathrm{C}$ [8].

Based on previous description, it should be known that anthocyanin easily changes on the structure. In this study, effect of solvent and heating $\left(40^{\circ} \mathrm{C}, 60^{\circ} \mathrm{C}\right.$ dan $80^{\circ} \mathrm{C}$ ) on anthocyanin stability has been done. Solvent used were ethanol and distilled water. Stability of anthocyanin was determined by calculation of total anthocyanin content using $\mathrm{pH}$ differential method (Inggrid et, all., 2016) and antioxidant activity using DPPH method (Molyneux, 2004) [9,10]. Analysis was done using UV-Vis spectroscopy.

\section{METHODS}

This research was conducted in several stages. Hibiscus sabdariffa Linn was extracted in ethanol solvents. Extract was concentrated using rotary vacuum evaporator at $37^{\circ} \mathrm{C}$ and vacuum conditions $60 \mathrm{mbar}$. Effects of solvent on anthocyanin stability was done by calculating total anthocyanin content as cyanidin 3-glucosides using spectrophotometry UV-Vis.

\section{II.1 Material and Tool}

Materials used in this study are dried roselle petals purchased from MojosongoBoyolali Indonesia, ethanol, $\mathrm{KCl}, \mathrm{CH}_{3} \mathrm{COONa}$, distilled water, methanol pro analysis (Merck, Germany), and $\mathrm{HCl} 37 \%$ (Merck, Germany), DPPH (2,2diphenyl-1-picrylhydrazyl). 


\section{II.2 Preparation and Anthocyanin Extraction}

Extraction of anthocyanin pigment was done using maceration at $25^{\circ} \mathrm{C}$ [8]. 100 $\mathrm{mg}$ of roselle petals powder macerated with $300 \mathrm{~mL}$ ethanol at $25^{\circ} \mathrm{C}$ for 24 hours. The produced filtrate then concentrated using rotary vacuum evaporator at $37^{\circ} \mathrm{C}$ and vacuum conditions 60 mbar.

\section{II.3 Effects of Solvent on Total Anthocyanin Contents as Cyanidin 3-glucoside}

Effects of solvent on anthocyanin stability was done by dissolving $0.025 \mathrm{mg}$ anthocyanin crude extract on $10 \mathrm{~mL}$ distilled water and ethanol. Each solution was analyzed the maximum wavelength at $400-800 \mathrm{~nm}$. Analysis of total anthocyanin content as cyanidin 3-glucosides was done using $\mathrm{pH}$ differential method.

\section{A. Preparation of pH 1 Solution}

$1.490 \mathrm{~g}$ potassium chloride $(\mathrm{KCl})$ was dissolved on distilled water using 100 $\mathrm{mL}$ volumetric flask. $25 \mathrm{~mL} \mathrm{KCl}$ solution mixed with $67 \mathrm{~mL}$ of $0.2 \mathrm{~N} \mathrm{HCl} .0 .2 \mathrm{~N} \mathrm{HCl}$ was added into the solution until $\mathrm{pH} 1.0 \pm 0.1$.

\section{B. Preparation of $\mathrm{pH} 4.5$ Solution}

$1.640 \mathrm{~g}$ sodium acetate was dissolved on distilled water using $100 \mathrm{~mL}$ volumetric flask. $0.2 \mathrm{~N} \mathrm{HCl} \mathrm{N}$ was added until $\mathrm{pH} 4.5 \pm 0.1$.

\section{Analysis of Total Anthocyanin Contents as Cyanidin 3-glucoside}

$0.050 \mathrm{~g}$ extracts was dissolved on $10 \mathrm{~mL}$ distilled water. This solution was split in half (5 mL each). Solution with $\mathrm{pH} 1.0$ dan $\mathrm{pH} 4.5$ was added into the extract solution. Absorbance of each solution was measured on 510 and $700 \mathrm{~nm}$. Absorbance of dissolved samples (A) calculated using :

$\mathrm{A}=\left(\mathrm{A}_{510}-\mathrm{A}_{700}\right)_{\mathrm{pH} \mathrm{1,0}}-\left(\mathrm{A}_{510}-\mathrm{A}_{700}\right)_{\mathrm{pH} 4,5}$

Total Anthocyanin content as cyanidin 3-glucoside of sample calculated using formula:

which:

$$
\text { Anthocyanin }(\mathrm{mg} / \mathrm{L})=\frac{A \times M W \times D F \times 1000}{\varepsilon \times L}
$$

$\varepsilon \quad=$ molar absorptivity molar cyanidin-3-glucoside $(26900 \mathrm{~L} /(\mathrm{mol} . \mathrm{cm}))$

$\mathrm{L} \quad=$ width of cuvette $(1 \mathrm{~cm})$

MW = molecular weight of cyanidin -3 - glucoside $(449,2 \mathrm{~g} / \mathrm{mol})$

$\mathrm{DF}=$ dilution factor

\section{II.4 Effects of Heating on Total Anthocyanin Content}

$0.50 \mathrm{~g}$ extract was dissolved on $100 \mathrm{~mL}$ distilled water (5000 ppm). Each solution was heated at $40^{\circ} \mathrm{C}, 60^{\circ} \mathrm{C}$, dan $80^{\circ} \mathrm{C}$ for 60 minutes. Total anthocyanin as cyanidin 3glucoside was calculated before and each 10 minutes after heating. the solution was stored for antioxidant activity test.

\section{II.5 Antioxidant Activity}

Antioxidant activity was determined before and after heating process. Each extract solution was diluted with variation of $25,50,75,100,125 \mathrm{ppm}$. DPPH 
solution was prepared by dissolving $20 \mathrm{mg}$ DPPH powder on $100 \mathrm{~mL}$ methanol. $2 \mathrm{~mL}$ extract solution was mixed with $2 \mathrm{~mL}$ DPPH solutions [10]. Incubation was done for 30 minutes. The Absorbance of samples were measured by UV-Vis spectrophotometer at $517 \mathrm{~nm}$ using methanol as blank. Antioxidant activity $\left(\mathrm{IC}_{50}\right)$ was determined using calibration curve between concentration versus \%inhibition. The \%inhibition was calculated using formula:

$$
\text { \%inhibition }=\frac{\text { A blank }- \text { A sample }}{\text { A blank }} \times 100 \%
$$

\section{RESULT AND DISCUSSION}

The discovery of anthocyanin compounds in a given plant has a meaning that is very strategic and important because it can be used as material for antioxidant activity. In addition, researchers in Indonesia is currently being excited doing bioactive compounds that are detected and quantifies in plant material. Hibiscus sabdariffa is used as a target plant in our laboratory because it is a tropical plant and reportedly has a prospective anthocyanin compound for treatment of coloring agent and antioxidant.

\section{III.1 Extraction of Anthocyanin}

Extract yielded by extraction are $7.9107 \mathrm{~g}$ and $7.91 \%$ yield with dark red color. Extract used for analysis on different test parameter

\section{III.2 Effects of Solvents on Total Anthocyanin Content as Cyanidin 3-O- glucoside}

The maximum wavelength of the extract dissolved in ethanol is $543 \mathrm{~nm}$, which has a tendency similar to the results obtained by Suzery, et al (2010) [8]. Whereas the maximum wavelength of distilled water obtained by distilled water is $519 \mathrm{~nm}$. Both of these maximum wavelengths are uptake of anthocyanin. According to Wallace and Guisti (2013) the maximum wavelength of anthocyanin is in the range of $480 \mathrm{~nm}$ to $550 \mathrm{~nm}[11]$.
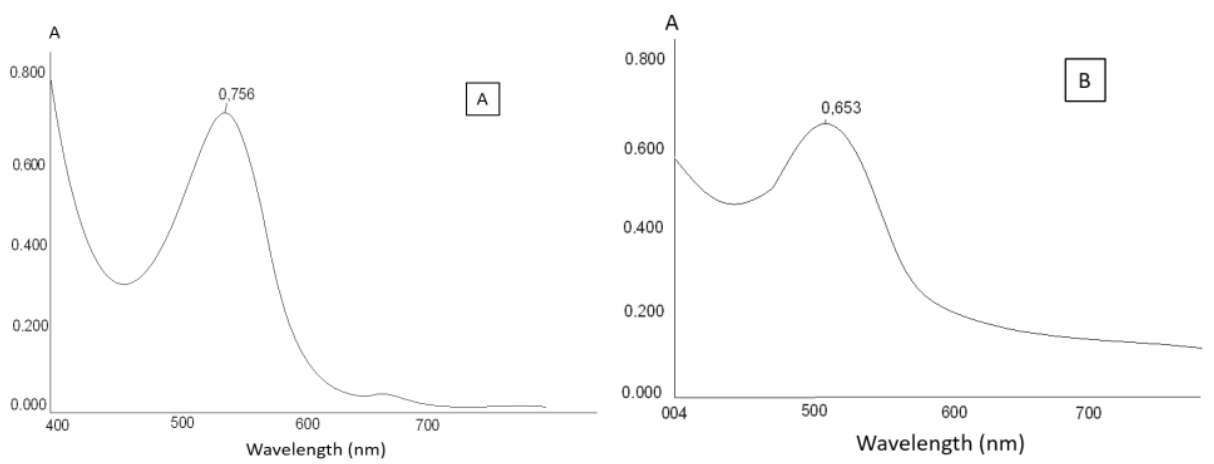

Figure 2. Spectrum of 400-800 nm wavelength (A) Ethanol (B) Distilled Water

The total content of anthocyanin as cyanidin 3-Glocoside obtained from distilled water was $144.28 \mathrm{mg} / \mathrm{L}$, while ethanol was $171.66 \mathrm{mg} / \mathrm{L}$. Ethanol solvent has a higher 
total anthocyanin content as cyanidin 3-glucoside than distilled water. Ethanol and distilled water have the same properties, polar. The dielectric constant value of ethanol is 25.10 while water is 80.10 [12]. The Anthocyanin tend to have the same polarity properties as ethanol, causing the total content of anthocyanin produced in ethanol is higher than in water. Therefore, the anthocyanin compounds were more stable in ethanol solutions than in water. Anthocyanins have better stability in very acidic $\mathrm{pH}$. This is evidenced by the anthocyanin dissolution test at $\mathrm{pH} 1$ and $\mathrm{pH} 4.5$. At $\mathrm{pH} 1$, the

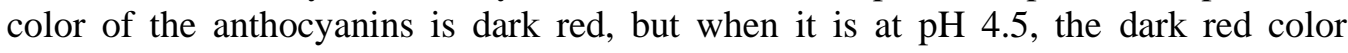
becomes faded. From the pH stability test, we also know that the main component in anthocyanins derived from roselle petals is cyanidin 3-glucoside. Cyanidin 3-glocisde containing in the Anthocyanin gives a red color.

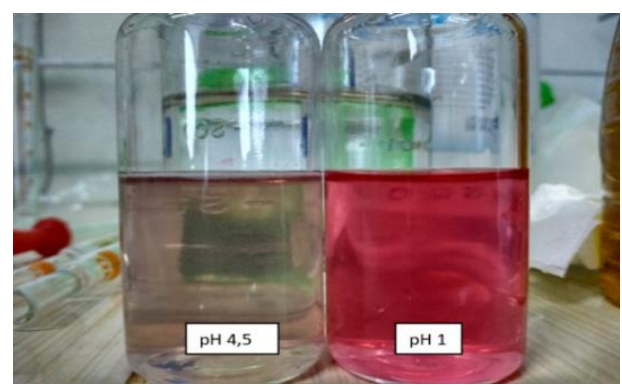

Figure 3.Anthocyanin colour depends on $\mathrm{pH}$

\section{III.3 Effects of Heating Process on Total Anthocyanin Contents}

Total Anthocyanin Content (TAC) of extract solution before heating was 144,28 $\mathrm{mg} / \mathrm{L}$. Meanwhile, total anthocyanin content 60 minutes after the heating at $40^{\circ} \mathrm{C}$ was $108,88 \mathrm{mg} / \mathrm{L}$; at $60^{\circ} \mathrm{C}$ was $88,84 \mathrm{mg} / \mathrm{L}$; and at $80^{\circ} \mathrm{C}$ was $63,78 \mathrm{mg} / \mathrm{L}$. Total anthocyanin content were changed after heating treatment due to the degradation of Anthocyanin structure [13]. Total anthocyanin contents at $80^{\circ} \mathrm{C}$ decreased up to approximately 80,5 $\mathrm{mg} / \mathrm{L}$. The total anthocyanin content in various temperature and time heating was showed on figure 4 .

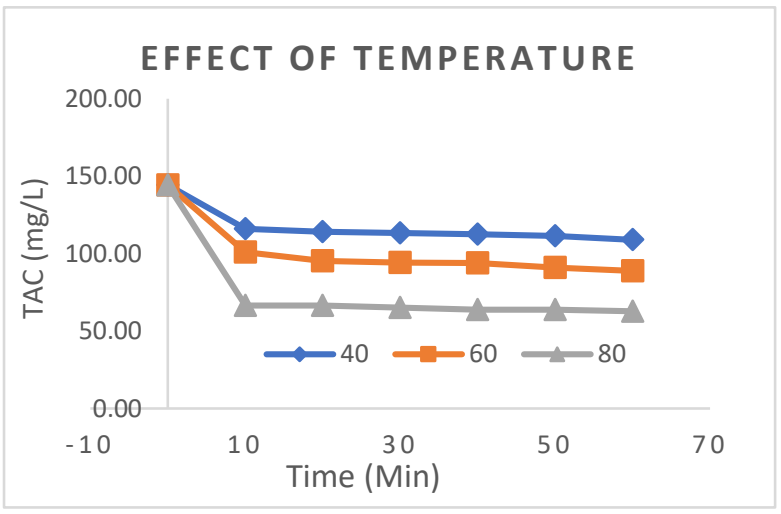

Figure 4. Anthocyanin concentration at temperature at $40^{\circ} \mathrm{C}, 60^{\circ} \mathrm{C}$ and $80^{\circ} \mathrm{C}$ 
Total anthocyanin content at $40^{\circ} \mathrm{C}, 60^{\circ} \mathrm{C}$, and $80^{\circ} \mathrm{C}$ tend to decrease until 60 minutes. As the rises of temperature, the more anthocyanin compounds were degraded [6]. Alteration of anthocyanin structure caused by increasing temperature happens with releasing of sugar molecules attached to anthocyanin structure, and transformation into aglycon named anthocyanidin. After releasing of sugar, there are cleavage process on the " $\mathrm{C}$ " ring. The result of cleavage bond separates the " $\mathrm{A}$ " ring and the " $\mathrm{B}$ " ring that induced formation of two new compounds there are Phloroglucinaldehyde and 4hydroxybenzoic acid. The cleavage process of cyanidin lead changing color of cyanidin. The degradation of cyanidin-3-O-glucoside structure can be seen on Fig 5.

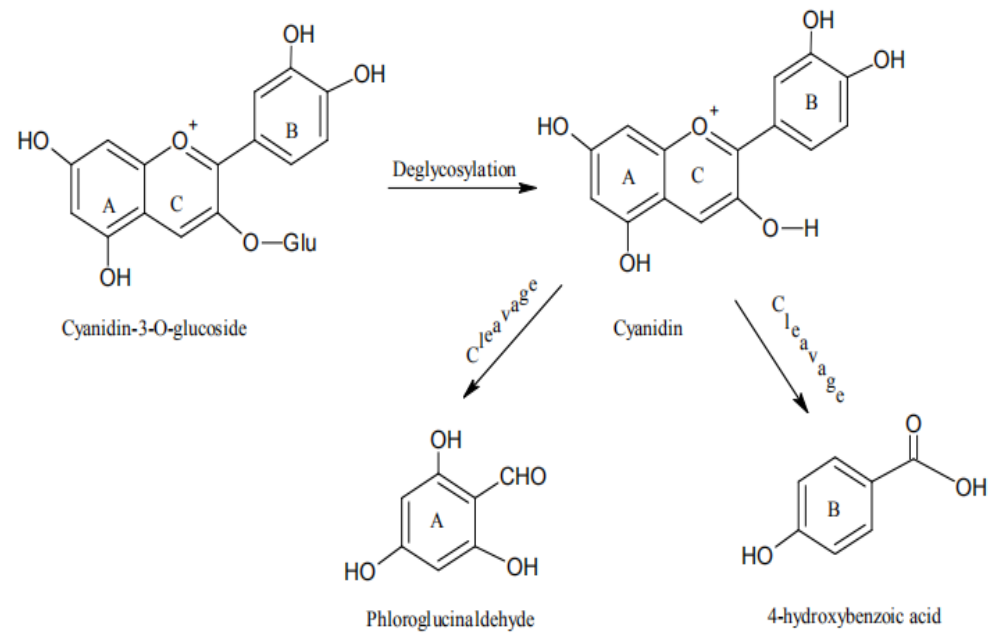

Figure 5. Mechanism of cyanidin-3-O-glucoside degradation

Table 1. Total anthocyanin content during heating process

\begin{tabular}{|c|c|c|c|}
\hline \multirow{2}{*}{$\begin{array}{c}\text { Time } \\
\text { (Min) }\end{array}$} & \multicolumn{3}{|c|}{ Total Anthocyanin Content } \\
\cline { 2 - 4 } & $\mathrm{T}: 40^{\circ} \mathrm{C}$ & $\mathrm{T}: 60^{\circ} \mathrm{C}$ & $\mathrm{T}: 80^{\circ} \mathrm{C}$ \\
\hline 0 & 144,28 & 144,28 & 144,28 \\
\hline 10 & 115,89 & 100,86 & 66,462 \\
\hline 20 & 114,22 & 95,18 & 66,462 \\
\hline 30 & 113,22 & 94,18 & 65,126 \\
\hline 40 & 112,55 & 93,85 & 63,790 \\
\hline 50 & 111,55 & 90,84 & 63,790 \\
\hline 60 & 108.88 & 88,84 & 62,788 \\
\hline
\end{tabular}




\section{III.4Analysis of Antioxidant Activity Using UV-Vis Spectroscopy}

Analysis of antioxidant activity was done to quantify anthocyanin compounds after heating. From the analysis using UV-Vis Spectroscopy obtained data that heating treatment causes $\mathrm{The}^{\mathrm{IC}} 50$ value of anthocyanin solution to increase. It means the degradation of Anthocyanin structure lead to decreasing of antioxidant activity. Therefore, Anthocyanin more stable at room temperature (without heating) than at heating temperature $\left(40^{\circ} \mathrm{C}, 60^{\circ} \mathrm{C}, 80^{\circ} \mathrm{C}\right)$. The calibration curve of Anthocyanin antioxidant activity was showed on figure 6 .

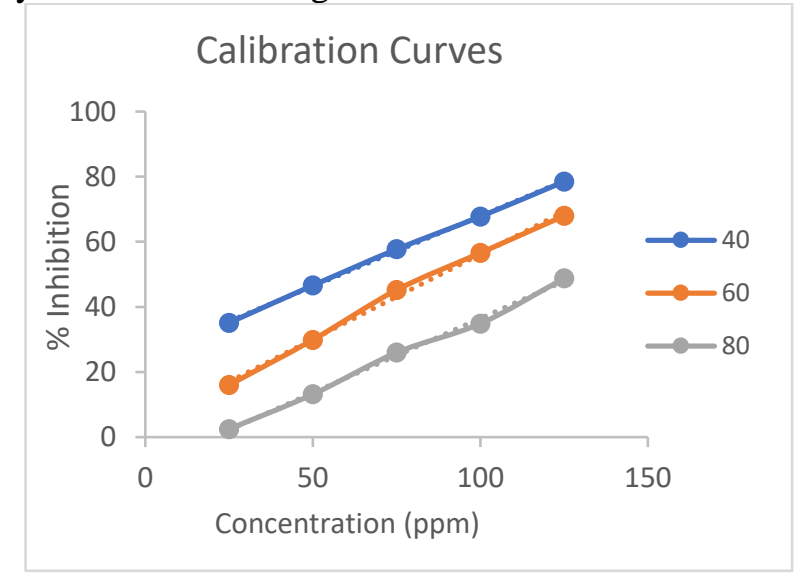

Figure 6. Calibration Curve at $40^{\circ} \mathrm{C}, 60^{\circ} \mathrm{C}$, dan $80^{\circ} \mathrm{C}$

Antioxidant activity of anthocyanin solution before heating has lower $\mathrm{IC}_{50}$ value $(42,81 \mathrm{ppm})$, while after heating treatment at $40^{\circ} \mathrm{C}, 60^{\circ} \mathrm{C}$, and $80^{\circ} \mathrm{C}$ show increasing $\mathrm{IC}_{50}$ value. Even the $\mathrm{IC}_{50}$ at $80^{\circ} \mathrm{C}$ was increasing up to $202,75 \%$ than before heating or more than twice. It means Anthocyanin structure was very sensitive with heating treatment and unstable in higher temperature. These results showed that heating process reduce the antioxidant activity of anthocyanin very much. The $\mathrm{IC}_{50}$ value of Anthocyanin showed in table 2.

Table 2. $\mathrm{IC}_{50}$ Before and After Heating

\begin{tabular}{|c|c|c|}
\hline Temperature & $\mathrm{R}^{2}$ & $\mathrm{IC}_{50}(\mathrm{ppm})$ \\
\hline Before heating & 0.984 & 42.81 \\
\hline $40^{\circ} \mathrm{C}$ & 0.994 & 57.64 \\
\hline $60^{\circ} \mathrm{C}$ & 0.995 & 88.15 \\
\hline $80^{\circ} \mathrm{C}$ & 0.996 & 129.61 \\
\hline
\end{tabular}

\section{CONCLUSION}

Extraction of anthocyanin compound from roselle petals was done using maceration. The types of Anthocyanin that extracted were Cyanidin-3-O-glucoside. 
Ethanol solvent can maintain total anthocyanin content $27,33 \mathrm{mg} / \mathrm{L}$ higher than aqueous solvent. Aqueous contain high water activity that can interact through hydrogen bonding with -OH groups that attach in Anthocyanin structure, that interaction lead to degradation of anthocyanin. The temperature was very influential on the stability of anthocyanin structure which then have impacts on antioxidant activity of anthocyanin. As the higher temperature the more unstable anthocyanin structure because the degradation of Anthocyanin structure happened. When the Anthocyanin structure were degraded the anthocyanin ability as an antioxidant also reduce.From this research, it was obtained data that anthocyanins without heating had the smallest $\mathrm{IC}_{50}(42.81 \mathrm{ppm})$ of antioxidant activity. This is because no anthocyanin compounds were degraded because of heating treatment.

\section{ACKNOWLEDGMENTS}

This research is part of the fundamental research that is funded from the Ministry of Research, Technology and Higher Education Republic of Indonesia.

\section{REFERENCES}

[1] Martins, N., Roriz, C. L., Morales, P., Barros, L. dan Ferreira, I. C., 2016, Food Colorants: Challenges, Opportunities and Current Desires of AgroIndustries to Ensure Consumer Expectations and Regulatory Practices. Trends in Food Science \& Technology52: 1-15.

[2] Gizir, A. M., Turker, N. dan Artuvan, E., 2008, Pressurized Acidified Water Extraction of Black Carrot [Daucus Carota Ssp. Sativus Var. Atrorubens Alef] Anthocyanins. European Food Research and Technology226(3): 363-370.

[3] Barhe, T. A., \& Tchouya, G. F., 2016. Comparative study of the anti-oxidant activity of the total polyphenols extracted from Hibiscus Sabdariffa L., Glycine max L. Merr., yellow tea and red wine through reaction with DPPH free radicals. Arabian Journal of Chemistry, 9(1), 1-8.

[4] Ngunjiri, P., Luvonga, W. A., Njoroge, M. dan Makokha, A., 2017, Chemical Characterisation of Hibiscus sabdariffa (Roselle) Calyces and Evaluation of Its Functional Potential in the Food Industry,JKUAT Scientific, Technological and Industrialisation Conference, 631- 638.

[5] Abdallah, E. M. (2016). Antibacterial activity of Hibiscus sabdariffa L. calyces against hospital isolates of multidrug resistant Acinetobacter baumannii. Journal of Acute Disease,5(6), 512-516.

[6] Patras, A., Brunton, N. P., O'Donnell, C. dan Tiwari, B., 2010, Effect of Thermal Processing on Anthocyanin Stability in Foods; Mechanisms and Kinetics of Degradation. Trends in Food Science \& Technology, 21, 3-11.

[7] Rein, M., 2005, Copigmentation Reactions and Color Stability of Berry Anthocyanins, Biochemical Engineering Journal, 14, 217-225. 
[8] Suzery, M., Lestari, S. dan Cahyono, B., 2010, Penentuan Total Antosianin Dari Kelopak Bunga Rosela (Hibiscus Sabdariffa L) Dengan Metode Maserasi Dan Sokshletasi. Jurnal Sains dan Matematika18(1): 1-6.

[9] Inggrid, H. M., \& Santoso, H., 2016,Natural red dyes extraction on roselle petals. Materials Science and Engineering Conference Series (Vol. 162, No. 1, p. 012029).

[10] Molyneux, P., 2004, The Use of the StableFree Radical Diphenylpicrylhydrazyl (DPPH) for Estimating Antioxidant Activity. Songklanakarin J. Sci. Technol26(2): 211-219.

[11] Wallace, T. C., \& Giusti, M. M. (2013). Anthocyanins in health and disease. CRC Press. Page .126

[12] Mohsen-Nia, M., Amiri, H., \& Jazi, B., 2010. Dielectric constants of water, methanol, ethanol, butanol and acetone: measurement and computational study. Journal of Solution Chemistry, 39(5), 701-708.

[13] Chumsri, P., Sirichote, A. dan Itharat, A., 2008, Studies on the Optimum Conditions for the Extraction and Concentration of Roselle (Hibiscus sabdariffa Linn.) Extract. Songklanakarin J. Sci. Technol, 30, 133-139. 